\title{
Africa's Strategies of Development and International Insertion: The Hybridity of Agenda 2063
}

\section{Guilherme Ziebell de Oliveira* Anselmo Otavio**}

\begin{abstract}
The present work discusses the evolution of the development and international insertion strategies adopted by nations in the African continent since the mid- $20^{\text {th }}$ century, period during which they began to achieve formal independence. In this context, supported by a literature review and official documents issued by African international organisations, the aim of this analysis is to understand the meaning and the importance of Agenda 2063 for this issue. Based on this analysis, the article proposes to demonstrate that such an agenda represents the inauguration of a new development and international insertion strategy in the continent, a hybrid one, that reconciles elements of two of the previously adopted approaches: the strategies of contestation and of mutual and shared responsibility.
\end{abstract}

Keywords: Africa; Pan-Africanism; African Renaissance; development; strategies; Agenda 2063.

\section{Introduction}

Since the mid- $20^{\text {th }}$ century, when the independence processes began to take place in Africa, one of the central concerns of political leaders in the continent was to achieve economic development. After centuries of exploration and dominance by extra-continental actors, the need to elaborate and implement new strategies became clear. These strategies should allow African countries to guarantee not only adequate living conditions for their populations, but also to foster a new insertion in the international system, both political and economic. Since then, nations in the African continent have sought to create, through its regional organisations - especially the Organisation of African Unity (OAU) and its successor, the African Union (AU) - strategies linking development and international in-

\footnotetext{
* Federal University of Rio Grande do Sul, Porto Alegre-RS, Brazil; guilherme.ziebell@ufrgs.br. ORCID iD 0000-0002-0118-6279.

** University of Vale do Rio dos Sinos, Porto Alegre-RS, Brazil; anselmootavio@gmail.com. ORCID iD 00000001-5560-4168.
} 
sertion that were supported by different ideologies and distinct economic and political projects.

In this vein, two strategies of development and international insertion adopted by the continent since the 1960s can be identified. The first was that of confrontation and contestation, predominant until the end of the 1970s. Inspired by the Pan-Africanist heritage, such an approach had, as one of its main expressions, the 1980 Lagos Plan of Action (LPA). Developed within the scope of the OAU, the LPA was not successful. Its results fell short of those expected by continental leaders, largely due to the emergence of neoliberal ideas and their consequences for Africa during the 1980s and 1990s.

This reality contributed to the development and adoption of a new strategy from the late $20^{\text {th }}$ century onwards. Keeping some inspiration in the Pan-Africanist thinking, and strongly marked by the idea of African Renaissance, this new approach demonstrated the willingness of countries in the continent to adapt to the fundamental precepts of neoliberal globalization, despite the fact that they sought greater protagonism in the definition and conduct of initiatives to address the challenges faced by them. Still, this strategy was based on the notion that the responsibility for African development did not fall exclusively on the nations of the continent, being shared with extra-continental actors - especially the great powers -, which should have an active role in this process. The transformation of the $\mathrm{OAU}$ into the AU and the creation of the New Partnership for Africa's Development (NEPAD) in the early $21^{\text {st }}$ century were the clearest expressions of the new strategy.

Throughout the 2000s, African countries underwent important transformations, largely considered to be the result of the new strategy for development and international insertion adopted by the continent. As a result, there has been a significant reduction in the number and intensity of violent conflicts, largely due to the AU's performance and to the organisation's frameworks (Burbach and Fettweis 2014). Also, several socio-economic indicators of a large portion of African countries have likewise undergone significant improvements. The consequence of these transformations was the renewal of Africa's geopolitical, economic, and strategic importance in international relations (Nagar and Mutasa 2018). However, a more in-depth observation of the transformations that occurred in the first decades of the $21^{\text {st }}$ century shows that such an improvement, even if expressive, was below the world's average and of other regions in the same period, indicating not a recovery of the continent, but an increase in the development gap (Oliveira 2018).

Faced with such a scenario, the search for continuity and deepening of the transformations seen in Africa, which were symbols of the African Renaissance, led the heads of state and government in the continent to create a new continental initiative, called Agenda 2063. Its elaboration was based not only on the lessons learned from past experiences, but also in the understanding that Africa had never been so strong and united, with strengthened and fully functioning regional organisations. In addition, the new initiative was also founded on the perception that the global context was undergoing important transformations that would provide new development opportunities for the continent.

The proposals of this initiative proved to be quite innovative, not only because of the actors involved in its conception and in its execution, but also because of the tools devel- 
oped and the objectives set. In addition, the most important characteristic of the initiative is the articulation of elements of Pan-Africanism, with its contestation strategy, and of the African Renaissance, with the ideas of adequacy and mutual responsibility (AUC 2015). In other words, Agenda 2063 does not break with the African Renaissance; in fact, it acts on the continuity of the transformations found in this transformative phase, yet it turns to the adoption of elements found in the contestation strategy.

Roughly speaking, this new approach seeks to reposition and adapt African countries to the multiple transformations that have been taking place in international relations since the beginning of the $21^{\text {st }}$ century. In view of this characteristic, this article aims to demonstrate that the interaction between contestation and mutual responsibility, in fact, represents the inauguration of a new African strategy, which aims to put development in conjunction with Africa's international insertion, classified here as hybrid. To this end, the article is based on a review of the literature and of official documents issued by African international organisations, focusing on the analysis of the elements that represent continuity and rupture in relation to previous strategies.

The work is divided into three sections, in addition to this introduction and to the final considerations. In the first and second sections, we discuss the first two strategies adopted by the continent - contestation and mutual responsibility - along with their respective ideational inspirations - Pan-Africanism, and African Renaissance - and their main political expressions - OAU, and LPA for the first, and AU, and NEPAD for the latter. The third section focuses on Agenda 2063, discussing not only its proposals and structure, but also highlighting its links with both Pan-Africanism and the African Renaissance.

\section{Pan-Africanism, the Organisation of the African Unity, and the Lagos Plan of Action}

In addition to inaugurating the Cold War, the power transition found in the immediate post-World War II was marked by two characteristics that are, in general, paradoxical. The first concerns the constitution of an international conjuncture favourable to the independence processes. This was mainly due to the fact that the European great powers were unable to maintain their overseas empires, while the USA and the USSR defended, to a greater or lesser extent, the right of all peoples to self-determination. The second characteristic refers to the inclusion of any independence process, or any conflict, such as civil and interstate wars, within the East-West dispute (Hobsbawm 1994). In this scenario, Pan-Africanism was the main driver of the processes of independence in Africa, the solving of the continent's challenges, and of the pursuit of a new international insertion.

The role and importance of Pan-Africanism for Africa can be divided into three phases, which correspond to the periods of gestation, consolidation, and of the challenges faced by the movement. The first period extends from the $19^{\text {th }}$ century to the early $20^{\text {th }}$ century, when Pan-Africanism started to be developed by figures such as Alexander Crummell, Edward W. Blyden, Marcus M. Garvey, and William E. Du Bois (Hernandez 2008). Among these, Du Bois' contribution needs to be highlighted. He had an active role 
in the fight against discrimination; in the promotion of the ideas of unity between Africans and the African diaspora; and was also an important supporter of the Pan-Africanist Congresses, held in Paris (1919), London (1921), Lisbon (1923), New York (1927), and Manchester (1945) (Ki-Zerbo 1999; M’Bokolo 2011).

Among these events, the last one was the most prominent, having been marked by two distinctive characteristics. The first refers to the participants, given that, for the first time since the creation of these conferences, the number of African-born representatives to attend was greater when compared to the number of participants from the diaspora. The second concerns the issues that gained prominence at the event, namely, the fight against racist and discriminatory laws; the abolition of forced labour; the right to vote, and to equal pay; and the activism for decolonisation and total independence of existing colonies on the African continent (Chanaiwa and Kodjo 2010).

Albeit a result of this period of genesis, the conference can be understood as one of the main events that marked the second phase of Pan-Africanism, which consolidated the movement. In fact, prior to Manchester, the consolidation of Pan-Africanism could be found in the theoretical-cultural sphere. For instance, in the 1920s, René Maran won the French literary prize Gouncort for the novel Batouala, becoming the first black man to receive it (Barbosa 2016). In the political dimension, signs of the movement's consolidation could be seen in the creation and performance of organisations such as the International African Friends of Abyssinia and the Ethiopian Research Council; both aimed at sensitising the international community with regard to the Italian invasion of Ethiopia.

After the Manchester Conference, other examples of the consolidation of Pan-Africanism could be found in the processes of decolonisation. In general, they were marked by the importance of the role played by literate minority groups (elites), which, although seeking to rescue an African past prior to imperialism, also valued modernity (Hobsbawm 1994). A reflection of this can be found in the division established between those who accepted and assimilated the capitalist and liberalising precepts defended by the European great powers; and those who showed to be refractory to such precepts, and endorsed socialism - valued for its anti-imperialist character and for presenting different strategies to achieve better living conditions for African citizens (Mendonça 2019).

Regardless of its impacts, this divergence, which was also a reflex of the Cold War, did not prevent what can be considered the culmination of this phase of consolidation - that is, the integration process. The establishment of the integration process was marked by the opposition between the Casablanca group (favourable to the creation of the United States of Africa, with a focus on planning and centralising economic development) and the Monrovia group (which defended both the maintenance of the sovereignty and territorial integrity of African countries, as well as the creation of a kind of confederation among States) ${ }^{1}$ (Cervenka 1977). Despite their divergences, both groups highlighted the importance of regional integration. The symbol of this perception can be found in the creation of the OAU in 1963, an initiative based on the self-determination of peoples; the ideals of freedom, justice, and equality; respect for human rights, among other principles that symbolised the fight against any form of domination inherited from the European 
imperialism. In the political sphere, the expression of this struggle is found in the military and financial support provided for the independence processes (Wallerstein 1967).

In parallel with regional integration, the phase of consolidation of Pan-Africanism was marked by the pursuit of another international insertion for the African continent, based on what we here call the contestation strategy. Such an approach was not restricted to Africa, being also found in the rest of the Third World. This block of countries, even though characterised by considerable political and economic diversity, had in common the fight against underdevelopment and the lack of representation in the international order established following World War II. In fact, in meetings or multilateral mechanisms such as the Bandung Conference (1955), the Non-Aligned Movement (1961), the G-77 (1964), and the Lusaka Conference (1970), it was possible to identify solidarity among Third World countries, the search for greater democratisation in the international order, and total rejection of North American interventions in the countries from the block (Vigevani 1994).

In the African case, the contestation strategy stood out not only in the political dimension, but also in the economic sphere, whose main objective was to break with external dependence and achieve authentic independence, that is, effective political and economic emancipation. This objective stood out as the Cold War period was marked by the difficulty in breaking with challenges in the economic sphere, despite the increase in the number of formally independent countries on the continent (Frieden 2008). A reflection of this can be found between 1960 and 1975, period during which Africa registered low growth in the agricultural sector (average of 1,6\%), in the manufacturing sector (around 6\%), and in exports in general (average of 2,8\%) (Bujra 2004). According to the Pan-African interpretation, these numbers symbolised the existing dependence of the African countries, whose exports consisted mainly of primary products and most imports of manufactured goods, on Western great powers - the main consumers of those primary products and exporters of manufactured goods.

Thus, breaking with any form of domination that resulted from the European imperialism meant breaking with this asymmetry. In this context, over the 1960s and 1970s, the OAU adopted several declarations and resolutions whose objective was not only to contribute to reducing African dependence in relation to developed countries, but also to guarantee its role in defining the continent's economic policies (Magee 1971). Among the declarations that stressed the importance of the continent's economic integration in the pursuit of such a purpose - such as Resolutions 158 (XI) from 1968 and 219 (XV) from 1970 - the 1973 African Declaration on Cooperation, Development, and Economic Independence needs to be highlighted. This declaration presented, among other claims, the African demand for the establishment of a New International Economic Order (NIEO) (Cervenka 1977). Even though they fell short of achieving the results they proposed, such actions demonstrated the OAU's concern with ensuring the authentic independence of the continent.

In 1989, with this same objective in mind, the OAU developed the LPA. Focused on the areas of agriculture, industry, infrastructure, science and technology, trade and 
finance, environment, among others, the Plan symbolised the contestation strategy. This was evidenced by the defence of points such as self-sufficiency, equity in income distribution, regional economic integration, valorisation of the expansion of the public sector in the industrialization process, and the creation of NIEO. Similar to the agenda defended by Third World articulations, the Plan stated that the NIEO should be fairer to the poor countries. All these claims contradicted the neoliberal economic model proposed by the capitalist powers at the time.

The emergence of the neoliberal ideology and consequently, the paradigmatic change concerning development, are linked to a series of events that occurred mainly between the 1970 s and the 1980s. Initially, the rise of this ideology related to the performance of the Organisation of Petroleum Exporting Countries (OPEC) which, facing the US unilateral rupture with the Bretton Woods agreement, the Yom Kippur War and the Iranian Revolution, increased the international price of oil, triggering two crises of global magnitude (in 1973 and in 1979, respectively). On the one hand, the increase in the price of oil led great powers, such as the USA, England, France, and Japan, to seek the creation of means to rationalise the use of the product and its derivatives. The impact of this process, associated with the increase in domestic inflation, was verified at the polls with the rise of Margaret Thatcher (1979) to the post of Prime Minister of the United Kingdom, and of Ronald Reagan (1980) to the US presidency. Both of these leaders were defenders of the neoliberal ideology and advocated its expansion to international organisations (Frieden 2008).

On the other hand, the recession that took place in great powers was accompanied by a restriction on the purchase of commodities that were widely exported by African countries. In this case, the decrease in exports led these countries to resort to foreign loans, which were used to finance development projects. However, financing development with these resources not only deepened dependency. It also ended up determining that any changes in developed countries would necessarily impact African countries. Impacts of this reality could be seen, for example, in the so-called Volcker shock in 1979, when the US Federal Reserve raised the country's interest rate, culminating in an exponential increase in the foreign debt of underdeveloped countries. The monetary policy adopted by the Reagan administration, equally marked by the adoption of high interest rates, also directly affected peripheral countries, including African states. Besides contributing to increase the indebtedness of the debtor nations once again, it also made the resources previously available for loans to be channelled to the American financial market, significantly reducing the volume of available credit and making access to new loans more difficult (Frieden 2008).

Faced with this scenario, African countries moved away from the contestation strategy symbolised by the LPA and adopted neoliberal policies. This had catastrophic consequences. Economic stagnation, a rise in unemployment, and the flight of skilled labour were coupled with the rise in foreign debt - which was of about US\$5b in 1970 and exceeded the US\$150b mark in 1991 - and with the decrease in the continent's share of international trade, with imports falling around $8 \%$ per year, and exports growing, on average, only $1,5 \%$ per year. In addition to not generating stability and development for 
African countries, neoliberalism has created or deepened political, economic, and social problems that have left severe lasting consequences to this day. In fact, besides the wars that resulted from the East-West dispute, neoliberal policies created conflicts related to rising poverty, hunger outbreaks, among other problems found in countries where the governments did not have the conditions of meeting the basic needs of the populations and, consequently, faced the collapse of the government and the state (Cardoso 2019).

\section{The African Renaissance, the African Union, and NEPAD}

The failure of the LPA, in addition to other challenges that were faced in the course of the 1990 s, relegated the continent to a marginal position in the globalisation process. In the security sphere, such marginalisation was a reflection of several conflicts that occurred on the continent, as seen in Liberia (1989-1997), in Sierra Leone (1991-2002) and in the Rwandan genocide (1994), among others (Schmidt 2018). In the economy, marginalisation went hand in hand with the preference developed countries had for investing in Latin American and Asian countries, and for importing mineral and energy resources from the former socialist bloc (DeLancey 2013; Cardoso 2019).

On the one hand, such a scenario helped to spread a simplistic and prejudiced view known as Afro-pessimism - the belief that Africa was doomed to failure and was dependent on external aid, given that the societies and cultures existing on the continent would be unable to break with economic stagnation and governmental instability (Bujra 2004). On the other hand, this scenario demonstrated the limits of the contestation strategy, as well as the need for African countries to develop another strategy that would couple development with international insertion, as well as break with Afro-pessimism. Endowed with this objective, another political and economic doctrine emerged on the continent, the African Renaissance, which brought with it the elaboration of a new strategy of action (Haberson and Rotchchild 2009).

Widely defended by Thabo Mbeki ${ }^{2}$, as seen in the speech delivered at the United Nations University in 1998 entitled The African Renaissance, South Africa and the World, the African Renaissance is commonly related to a set of external and internal dynamics that, from the late 1990s, unleashed a series of favourable opportunities to the African continent (Mbeki 1998). Externally, this scenario was the result of the interest of traditional and emerging powers in strengthening ties with African countries (Abegunrin 2009). In that sense, the creation of the Initiative for Africa, developed by the Clinton administration, and of the Forum on China-Africa Cooperation (FOCAC), can be highlighted. Both of these initiatives, with specific exceptions, were aimed at strengthening ties with African countries. In the domestic scenario, the dynamics favourable to the continent was a reflection of changes such as economic growth; the end of authoritarian regimes - especially the segregationist regime of apartheid in South Africa; the decline in the number of wars; among others (Otavio 2017).

However, in addition to giving name to such dynamism, the African Renaissance symbolises a new doctrine aimed at the political and economic renewal of the continent. 
Presenting common points with Pan-Africanism, which demonstrates the convergence of objectives, the two currents differed on the strategies proposed to achieve such goals. Regarding the similarities, the first concerns the interest in rescuing African history prior to European domination, highlighting a past marked by the existence of great civilizations, cultural wealth, and their importance in the history of humanity (Mbeki 1998; Otavio 2017).

A second similarity is related to the valorisation of African solidarity, fundamental in the search for independence since co-operation among countries was fundamental, in several cases, to the break of the colonialism. In the post-Cold War scenario, this solidarity remained as an important means for countries to find solutions to challenges that plagued the continent (Adebajo 2013). Such co-operation reflects the greater appreciation of regional integration, a process that has been gaining ground mainly in the $21^{\text {st }}$ century. However, the solution to these challenges is also related to another characteristic of the African Renaissance, namely, its strategy to deepen the transformations that were happening on the continent. Differently from the contestation strategy, the new approach was defined as a strategy of mutual or shared responsibility.

In general, this strategy seeks to break with Afro-pessimism, rescuing and valuing the continent's past, as well as presenting the world with a new Africa, willing to fight its afflictions. Besides that, the strategy links the African development to global political and economic dynamics, once that, by placing Africans back in control of defining the continent's direction, it seeks to break with the paternalistic relations symbolised by the donor-and-recipient pattern. In other words, it is expected that, on the African side, countries will commit to fighting corruption; acting in conflict resolution; and valuing elements such as democracy, human rights, the environment, among other points which are symbols of the international post-Cold War scenario. In return, the great powers must guarantee the access of African products to their markets; invest in the countries of the continent; as well as assist, directly or indirectly, in initiatives aimed at promoting the eradication of poverty, democratisation, and the pacification of Africa.

The notion of mutual or shared responsibility, as well as other characteristics of the African Renaissance, can be found in the political sphere and in the economic dimension. In politics, the transformation of one of the main symbols of Pan-Africanism, the OAU, into the African Union stands out. Initiatives or movements that symbolised interest in such a change have existed on the continent since at least the 1990s. An example thereof can be found in the Kampala Movement, which proposed the creation of the Conference on Security, Stability, Development, and Co-operation in Africa (CSSDCA). The CSSDCA was a mechanism aimed at conflict prevention and military self-sufficiency in Africa. The process of effective transformation, in this context, started to occur after the Extraordinary Session of the OAU held in Sirte, Libya, in 1999 (Oliveira, Calvete and Cardoso 2015).

Similar to the OAU creation process, the transition to the AU was also marked by two groups with divergent proposals. The first refers to Libya's interest in creating the United States of Africa, that is, moving the continent towards the formation of a Federalist State, thus rescuing the perspective of the Casablanca group. Conversely, the second propos- 
al was led by Nigeria and South Africa, countries that defended the conservation of the sovereign states, and understood that the OAU should be a protagonist in inter-African relations. However, while Abuja defended the characteristic points of the Kampala Movement, Pretoria emphasised that the organisation should not only create norms, principles, and a new structure, but also regulate the conduct of the member states in order for them to respect and accept the resolutions adopted under the organisation's scope (Landsberg 2012).

At the end of the 1999 Extraordinary Session, what was seen was the beginning of the process of transforming the $\mathrm{OAU}$ into the $\mathrm{AU}$, and the predominance of the proposals made by the second group, since the valorisation and construction of principles, institutions, political structures, and mechanisms that could regulate the behaviour of states were embodied by the AU. Even if some points defended by the OAU remained relevant such as the promotion of peace; the search for increased integration and solidarity among member states; the respect for sovereignty, territorial integrity, and independence of African States, the AU incorporated new issues, such as the valorisation of democracy, of human rights and, mainly, of the right of intervention by the Organisation in situations related to war crimes, genocides, and crimes against humanity (AU 2000; Landsberg 2012).

Additionally, it is worth highlighting some specificities of the AU that symbolise African solutions to the continent's challenges, one of which can be found in the Council of Elders, proposed by Nigeria since the establishment of the Kampala Movement. The Council aimed at peace-making through the mediation of great leaders, who outstood for fighting for independence or for their activism in solving challenges in their countries and, therefore, were respected across the continent, including among conflicting parties. The establishment of the African Peer Review Mechanism (APRM) is also worth mentioning. The purpose of APRM is to ensure greater cooperation between member states, as well as transparency in their electoral processes. Along with these initiatives, it is worth highlighting the recognition of the Regional Economic Communities (RECs) as instruments that dynamised the prevention and resolution of conflicts that have arisen in Africa (Kuwali 2018).

In the economic sphere, the strategy of mutual or shared responsibility has its main expression in NEPAD, a development plan for Africa with an alternative approach to African problems as that of international financial institutions. Focused mainly on reinserting the continent in the debates for its own development (Taylor 2005), the New Partnership originated from the merger of two competing projects, the Millennium Partnership for the African Recovery Program (MAP) and the Omega Plan.

The first appeared in 1996. Among its central objectives was the promotion of a dialogue with international financial institutions (such as the IMF and the World Bank) and with the developed great powers (especially the members of the G7+1). This dialogue was aimed at enabling a political, economic and social recovery of Africa through the commitments that were made not only by African countries, but also by the great powers and international institutions (De Waal 2002). The Omega Plan, in turn, sought to allow the 
continent to obtain benefits from the globalisation process, receiving funding for several projects (Martin 2002).

In 2001, during the fifth Extraordinary Session of the OAU, African leaders recognised the relevance and complementarity of both initiatives, and decided for the unification of the two projects. The result of this process was the creation of NEPAD, which had as its main objectives the eradication of poverty; the promotion of growth and sustainable development in African countries; the combating of the continent's marginalisation in the globalisation process; the search for a complete (and beneficial) integration of the continent into the global economy; the establishment of conditions for the sustainable development of Africa; and the guarantee of peace, security, respect for human rights and democracy on the continent (Oliveira 2018).

To a large extent, the objectives established by the Partnership were consistent with the Millennium Development Goals (MDGs), established by the UN in the early 2000s. This was a way of trying to guarantee the effective commitment of extra-continental partners - especially the Western great powers - with African development, since they would also have ratified the MDGs, being co-responsible for their fulfilment (De Waal 2002). Thus, the implementation of the NEPAD was expected to contribute in terms of attracting more resources to the continent. In this sense, the Partnership established as fundamental elements the good governance as a precondition for peace; the security; the sustainable political and socio-economic development; and a broader and deep participation of all sectors of society (Fombad 2006).

The main differential of the NEPAD in relation to the LPA is the fact that it leaves the dimension of contesting the international order, accepting the reality of globalisation and, simultaneously, establishing the notion of shared or mutual responsibility as a strategy to achieve the continent's economic development (Otavio 2017). In this vein, the NEPAD (2001: 2 [emphasis added]) presented itself as 'a call for a new relation of partnership between Africa and the International Community, especially the highly industrialised countries, to overcome the development hiatus that was widened over centuries of unequal relations', which was partly due to the acknowledgment, by the Partnership itself, of the failures of previous programs - and hence of the contestation strategy.

For some authors, the NEPAD achieved an important success within its proposal. It was well received by the developed partners and also by the International Financial Institutions. The G7+1 member countries, for example, pledged to develop a 'plan of action' aimed at the Partnership, which materialised at the Group Summit in June of 2002 in Kananaskis, Canada, as the Africa Action Plan from G7+1 was made official (NEPAD Agency 2011). In this context, the NEPAD would be a great success and a fundamental element both for the reorganisation and for the renewed importance of the African continent in the $21^{\text {st }}$ century, especially due to the elements of 'self-criticism' contained in the initiative. Among its greatest successes would be the placement of issues such as democracy and good governance at the centre of the African development agenda, thereby ensuring the participation of developed countries, especially the European Union, in the resolution of the continent's development challenges (Ottosen 2010). 
For others, however, not only the effectiveness of the NEPAD, but also the defence of the African continent's adaptation process started being questioned. One of the main criticisms comes from authors who consider the initiative to be excessively linked to the neoliberal ideology and, therefore, endowed with little capacity to effectively produce positive changes in Africa (Döpcke 2002). Thus, more than a vector for change and transformation, this partnership, in fact, would serve as a tool for perpetuating the traditional structures of the great powers' domination over African countries (Murithi 2009). By accepting globalisation uncritically, considering the adaptation to it as inevitable, the NEPAD would eventually incorporate the liberal discourse defended by traditional great powers, transforming itself not into an African response to this reality, but in a form of 'Africanisation' of the Western liberal proposals (Taylor 2005).

Despite being a program designed by Africans, and for Africans, maintaining dependence on aid and resources from central powers would still limit the NEPAD excessively. In view of this, the partnership would end up becoming equivalent to the Structural Adjustment Plans of the 1980s, imposed by international financial institutions. In fact, the concern to integrate African economies with developed countries would present a much greater potential of giving continuity to the exploitation of African human and natural resources by the central powers than to promote a break with the previously established pattern (Akinola and Ndawonde 2016). In this sense, even if the objectives established by the NEPAD were well-intentioned, the vision of development and the economic measures designed to achieve them would be problematic (Badiru 2016). Thus, the Partnership would be unable to effectively contribute to solve the development problems of the African continent, in fact reinforcing the hostile external environment and the internal weaknesses that constitute the greatest obstacles to the African development.

Another important criticism concerns the notions of democracy and good governance, since the defence of both elements as pre-requisites for economic development would not be supported by historical examples. In this vein, what could be identified, in fact, was an inverse relationship, in which economic development would be a pre-condition for the advancement of democracy and good governance (Chabal 2002). In this context, the transformations that took place on the continent, especially since the end of the Cold War - with the proliferation of multi-party regimes and the holding of democratic elections (at least formally) -, would not have been responsible for generating representative impact on the economic development of Africa. In other words, the focus given by the NEPAD on democracy and good governance would not have contributed to the development, but would have helped to align the continent to democratic orthodoxy. Therefore, the desired partnership, in fact, symbolises the commitment of African elites to the perpetuation of unequal relations between African countries and the international community, and not a break with this historical pattern (Oliveira 2018).

Over the first fifteen years, it is a fact that in some figures, especially in trade and in Foreign Direct Investment (FDI), the NEPAD presented positive results. In international trade, this can be found in the interaction with the United States. In 2005, the country exported US $\$ 15,5 \mathrm{~b}$ to the African continent and imported US\$55,3b; in 2015, these figures 
reached, respectively, US\$27,04b and US\$65,3b (ITC 2018). Regarding the entry of FDI in African countries, if in the early 1980s the average was US\$400m, in 2015 this figure reached US\$56,7b (UNCTAD 2018). However, and paradoxically, these same numbers ended up showing the NEPAD's fragility and, consequently, the limits in the strategy of mutual responsibility.

These limits were evident, firstly, because in the commercial sphere, even though the United States has expanded its interaction with African countries, it is in fact China that has become the continent's main trading partner. In figures, if in 2005 Beijing imported US\$11,8b and exported US\$18,6b to Africa, in 2015, these values were, respectively, US $\$ 77,6 \mathrm{~b}$ and US $\$ 105,8 \mathrm{~b}$ (ITC 2018). In addition, there was no increase in the African share of world trade. Even though there was a relative growth in exports of manufactures from $1 \%$ in 2000 to $1,3 \%$ in 2008 , in this same period African participation in the trade of low value-added goods dropped from $25 \%$ in 2000 to $18 \%$ in 2008 (UNCTAD 2011). Secondly, and no less important than what was previously mentioned, FDI tended to enter areas that, historically, have always been targeted by industrialised great powers, that is, regions rich in mineral and energy resources. In fact, in 2013, the sum of foreign investments in West and North Africa - respectively around US $\$ 14,5 b$, and US $\$ 12,7 \mathrm{~b}$ - was equivalent to $53,6 \%$ of the total FDI that entered the African continent (UNCTAD 2018).

\section{Agenda 2063 and the new African strategy}

The Chinese presence on the African continent, found in initiatives such as FOCAC, in technical cooperation, increased trade, and high investments, is indeed part of a process marked by the greater insertion of emerging powers in Africa (Carmody 2011; Abegunrin and Manyeruke 2020). A reflection of this process can be found in the Indian case, whose initiatives are related not only to trade, but also to cooperation in areas such as education, technology, and food security. The Brazilian case is also a sign of this new pattern of relation. Throughout the first decade and a half of the $21^{\text {st }}$ century, the South-American country opened or reopened embassies and consulates, expanded trade relations, and increased its co-operation with the continent, creating initiatives such as PROSAVANA (together with Japan and Mozambique) and Cotton-4 (carried out with Benin, Burkina Faso, Chad, Mali, and Togo) (Amorim 2010; Manpilly 2013; Milani 2014; Abdenur 2015).

On the one hand, the presence of the emerging powers presents the African continent with a new path to achieve development, through what is known as South-South Cooperation (SSC). The genesis of SSC concerns the relations among Third World countries and, unlike the North-South Cooperation (NSC), a pattern followed by traditional great powers, is marked by the absence of political conditionalities. On the other hand, and in response to the greater presence of emerging countries in Africa, what was seen was the return, or the increase in the activities, of traditional great powers on the continent. For instance, the creation of the Unified Combatant Command for Africa (AFRICOM) in 2007 , is a sign of this renewed interest. AFRICOM is a US initiative that, although officially aimed at pacifying the African continent through co-operation in the field of security, 
in fact, guarantees Washington access to natural resources in certain countries (Mangala 2010). In addition to AFRICOM, it is worth mentioning the intervention in Libya in 2011, orchestrated by NATO members that aimed mainly, among other objectives, to end the Gaddafi administration - which was achieved with the assassination of the Libyan leader (Oliveira 2015).

Given this scenario, two main elements signalled the limits of the strategy of mutual or shared responsibility. The first concerns the traditional great powers, whose examples previously mentioned demonstrated that their interests, in many cases, went in the opposite direction to the objectives of African countries. The second refers to the characteristics of the SSC, as disagreements in relation to the NSC are not merely nominal, but, fundamentally paradigmatic in what concerns the concept of co-operation (without political conditionalities), and how well-being can be achieved (mutual benefits and horizontality among those involved). Given these characteristics, as well as the challenges related to the greater concentration of FDI in some regions, and the maintenance of low participation in international trade, the strategy of mutual responsibility came to be questioned and, consequently, what we call the hybrid strategy of international insertion started to gain relevance.

By hybrid strategy, or hybridism, we understand the approach in which there is the maintenance of fundamental elements present in the African Renaissance, simultaneously to the rescue of elements of the contestation strategy that was central to Pan-Africanism. Regarding the contestation strategy, its adoption is seen not only in the increase of questioning about foreign interference, but mainly in that it breaks with initiatives considered prejudicial or of little advantage to African countries. With regard to the African Renaissance and its strategy, there is a management of interest in regional integration, in African solutions to African challenges, as well as the continuity of partnerships, however, no longer based on paternalism or assistance, but based on horizontality and mutual benefits.

A first expression of hybridism can be seen in 2010 in the city of Kampala, Uganda, with the launch of the Programme for Infrastructure Development in Africa (PIDA), the result of articulations between the African Union, the NEPAD, the United Nations Economic Commission for Africa (UNECA), and the African Development Bank (AfDB). The objective of this programme is the creation of means capable of dynamising the regional economic integration. In fact, challenges such as the high cost of transportation, excessive taxation, and the lack of stability in certain countries become factors that hinder the increase in trade between countries on the continent (Rodrigues and Caputo 2014). A reflection of this can be found in the comparison of the proportion of inter-African trade with that of other regions. If among the countries of the continent the volume of trade is around 15\%, in Europe, North America, and Latin America, this rate is of $68 \%, 37 \%$, and $20 \%$, respectively (Afreximbank 2018).

Similar to Pan-Africanism, the PIDA expresses the need for states to act together. This African solidarity goes hand in hand with the increased participation of the countries of the continent in the Programme, which, in 2012, reached a total of US\$42,2b. With regard to the African Renaissance, this initiative comes close to the NEPAD in terms of seeking 
external partnerships to overcome the existing infrastructure bottlenecks on the continent. An example of this effort can be found in the inflow of external resources, which in 2013 reached the amount of US\$99,6b. The biggest investor in this program is China, a country that in 2017 had already invested US $\$ 19,4 \mathrm{~b}$, far higher than the amount coming from countries such as the United States, France, Germany, the United Kingdom, Japan, and India, which, combined, reached US\$6,94b (ICA 2013, 2014, 2018).

However, hybridity as an actual strategy of development and international insertion finds in 2015 its main expression: the Agenda 2063. In general, the Agenda is marked by four characteristics. The first concerns the priority given to points considered central to the development of the African continent. Regarding this, the Agenda highlights eight areas (African identity and renaissance; the ongoing struggle against colonialism and the right to self-determination; continental integration; social and economic development and transformation; peace and security; democratic governance; the leading role in the determination of the continent's future; and the strengthening of Africa's space in the world). All these elements are considered fundamental to bring Africa to a new reality (AUC 2015; Deghetto, Gray and Kiggundu 2016). Along with this characteristic, it is worth stressing the special attention given to young people, women, and Africans in the diaspora. In this case, it can be highlighted the complete rejection of gender-based discrimination, the elimination of practices harmful to women (such as genital mutilation and child marriage), and full gender parity, with the expectation that by 2063 women will be occupying at least $50 \%$ of public posts on the continent (AU 2015).

The second characteristic concerns the structuring, planning, and implementation of the Agenda. In addition to setting the objectives previously indicated in seven primary aspirations, which serve as a foundation for the programme, the Agenda establishes goals of short (10 years), medium (25 years), and long (50 years) terms (Deghetto, Gray and Kiggundu 2016). The short-term goals are defined based on the planning of the elaboration of five successive ten-year plans, focused on issues pertinent to that specific period, and also aligned with the different stages of the program, and with the expected results for 2063 (AUC 2015). Examples of short-term objectives can be found in goals such as the end of all vestiges of colonialism on the African continent - with the end of occupations in the Chagos Archipelago or on the Mayotte Islands - and the silencing of all guns $s^{3}$, both objectives which were expected to be fulfilled by 2020. In the medium and long terms, it is worth highlighting the modernisation of agriculture, that banned the hoe by 2025, and the growth projection of the intra-African trade, equivalent to $12 \%$ in 2013 , to $50 \%$ in 2045 (AU 2015).

The third characteristic relates to the actors involved in the creation and implementation of the Agenda 2063. Although the importance of the states is highlighted, since the implementation of projects and the achievement of goals are carried out at the national level, the processes of conception, monitoring, and implementation of the Agenda are based on the articulation and interaction among national, regional, and continental levels - to which different roles and responsibilities are attributed. In this sense, at the continental level, the AU Commission, the NEPAD Planning and Coordination Agency (NPCA), 
AfDB, and UNECA are highlighted. Such actors were fundamental to the perception that the global context was undergoing important changes, which could represent new opportunities of development and investment for the continent. They also had a key-role in realising that Africa was undergoing a transformation. If in previous moments the continent had never been so strong and united, at that moment its regional organisations were strengthened and in full operation (AUC 2015).

The fourth characteristic concerns the tools for the feasibility and implementation of Agenda 2063, especially with regard to its financing. ${ }^{4}$ On the one hand, the program seeks to articulate goals that allow, simultaneously, for the realisation of its aspirations and the reduction of the dependence on aid and foreign capital flows in the financing of the continent's development. In this sense, the program seeks to develop African financing mechanisms. On the other, it is symbolic that, in a textual form, there are explicit references to the expectation of cooperation, to complement the financing of the Agenda, with 'emerging partners, such as the BRICS countries, the Arab world, etc.' (AUC 2015: 16), without any mention of the developed great powers. This element, therefore, demonstrates a drive away from the perspective sustained until then by the NEPAD. Moreover, it demonstrates the recognition of changes in the international financial architecture, marked, among others, by an increase in the role and power of emerging powers, as well as in the role of these actors in the transformation of FDI flows into the continent - with an increase in the importance of sectors other than commodities (AUC 2015).

On the one hand, the points previously presented reflect one of the main characteristics of mutual responsibility, that is, the state's role in continuing the transformations at the continental level, and, at the internal level, in the adoption of policies considered relevant for the socio-economic and socio-political well-being of Africans. In fact, Agenda 2063 highlights among its aspirations the valorisation of good governance, democratic values, respect for human rights, gender equality, rule of law, defence of the environment (AU 2015), among other issues that gained relevance in the post-Cold War era and that, roughly speaking, are symbols of the African Renaissance.

On the other hand, the same characteristics also rescue Pan-Africanism. This movement is constantly referenced in the symbolic documents of Agenda 2063 - the Framework Document, the Popular Version, and the First Ten-Year Implementation Plan (AUC 2015). In fact, in addition to the fight against any vestiges of colonialism and respect for the self-determination of the peoples - expressed, for example, in the favourable positioning for the independence of Western Sahara, the rescue of the African past prior to the European invasion is also highlighted. In this context, the need for pan-African ideals to be included in school programmes, as a way of spreading the continent's cultural heritage, such as folklore, music, religion, literature, and African languages gains relevance. According to the expectations of Agenda 2063, this will be the basis for continental administration and integration (AU 2015).

With regard to continental integration, although it was desired by mutual responsibility - as seen with the creation of the NEPAD, with the transition from the OAU to the $\mathrm{AU}$, and with the greater appreciation and protagonism of RECs - in the hybrid strategy 
the integration has elements which resemble those of the contestation strategy. Firstly, because it fits into integration in terms of African solidarity, this can be seen, for example, in the processes of independence and in the fight against apartheid. Secondly, because the year found in the title of the African proposal is not merely illustrative, but rather, it brings with it a symbolic and important character of the continent's history, since it marks the centenary of the creation of the OAU, in addition to representing the maximum term for the realization of long-term goals.

Thirdly, and possibly more important than the abovementioned elements, integration is seen as one of the main - if not the main - instruments aimed at the political and economic independence of Africa. In addition to promoting the free mobility of people, capital, goods, and services, it brings as a purpose the self-sufficiency and self-financing of projects directed at solving existing challenges on the continent. Also, in a similar way to the PIDA, Agenda 2063 conditions the continent's greater integration, its pacification and independence, to a quest to improve African infrastructure. Examples of this can be found in the prominence given to the creation or expansion of oil and gas pipelines and telecommunication networks - such as broadband networks, and in the attention dedicated to road, air, naval, and rail transport, with the expectation of consolidating high-speed rail networks connecting all the main cities and capitals of the continent (AU 2015). In that sense, with such infrastructure, an increase in trade on the continent is expected and, consequently, the development of African countries and the increase in the continent's share of world trade.

In this sense, the achievement of development will most likely enable the fulfilment of the African desire for a new international insertion, previously sought through the strategies of contestation and mutual responsibility. However, hybridism demonstrates that the implementation of Agenda 2063 would not only transform the continent into an increasingly integrated and developed space, but that such successes could transform Africa and its nations into major players in the international system. Thus, these states would be autonomous players, defenders of peaceful coexistence, and would have great participation and influence on global issues, notably the fight against xenophobia and racism, international cooperation and the preservation of the environment, among others considered important for the continent. In this same position, hybridism hopes to increase African performance in multilateral organisations, acting collectively in order to seek reforms at the United Nations, with emphasis on the Security Council - a space considered unfair since the continent is not permanently represented - as well as in other institutions.

Although the expectation for such a protagonism would be achieved closer to the end of Agenda 2063's implementation period, it is possible to already find initiatives created after the launch of this agenda that bring in their essence hybridism as a mechanism for enhancing development and international insertion. For instance, the questionings and the threat to leave the International Criminal Court (ICC) en bloc in 2016 point to this direction. In this occasion, the AU presented criticisms to the Court in a Decision released in 2018, which led to the dissatisfaction of African leaders, who questioned the criteria adopted by the Court, since most of the defendants were Africans. In addition, it is worth 
mentioning the African Continental Free Trade Area (AfCFTA), an initiative created in 2018, which was expected to come into force in 2020. In this case, the increase in intra-African trade projected by the AfCFTA will symbolise the decrease in external dependence, as well as the strengthening of the African continent vis-à-vis the international system.

\section{Conclusions}

The creation of strategies that reconcile development and international insertion can be considered as one of the main attempts of the African continent in its recent history. As analysed in this article, a first approach, whose genesis was linked to Pan-Africanism and that hereby was called the contestation strategy, predominated during the Cold War. Although it was successful in the political dimension, with considerable impacts on the processes of independence of African nations and in the creation of the OAU, in the economic and the security scopes, it proved to be limited, since it failed to eliminate both the economic dependence and the existing conflicts in Africa. A second approach that represents these efforts concerns the mutual responsibility strategy, which throughout the final years of the 1990s and the first decade of the current century influenced the creation of initiatives such as NEPAD and the transition from the OAU to the AU.

On the one hand, both contestation and mutual responsibility strategies present similarities that are not restricted to convergence in their purpose. In this case, a first characteristic relates to African activism in seeking solutions to the challenges that exist on the continent, since the creation, consolidation, and adoption of such strategies reflect, fundamentally, their multilateral character and the search for solutions via integration. Along with this activism, a second characteristic can be found in the fact that both are African responses to different international scenarios.

Symbol of the struggle against imperialism, and of the quest for development and pacification of the continent, the contestation strategy was the African response to the dispute between the USA and the USSR. Therefore, in addition to getting closer to the agenda defended by the Third World, the contestation strategy sought both to break with foreign interference in continental issues, as well as to achieve authentic, that is, political and economic independence. Conversely, mutual responsibility took into account the post-Cold War international scenario, marked by the predominance of traditional great powers and neoliberal ideas. In this sense, its response was to link the political, economic, and security solutions needed by African countries to the acceptance of values widely appreciated and spread by the West, especially liberal democracy and neoliberalism.

Finally, a third similar characteristic between contestation and mutual responsibility strategies concerns the fact that both are instruments created and adopted in favour of African interests. Thus, although such strategies represent different conceptions on how to achieve development and enhance international insertion, in reality, they do not exclude any of the two doctrines of political and economic renewal in Africa. In general, this similarity ends up highlighting one of the main characteristics of the African Renaissance, namely, its greater adaptability to changes in the international system. 
In fact, while Pan-Africanism is essentially - or almost exclusively - linked to the contestation strategy, the African Renaissance was able to move from the greater appreciation of traditional partnerships, such as the USA and the European Union, to the interest in strengthening ties with the emerging powers, notably China and the BRICS group. This flexibility also shows that there is no exclusion in relation to the points defended by Pan-Africanism for the African Renaissance. An example thereof can be found in the rescue of African history before the European invasion and in the greater appreciation of both continental solidarity and integration, points that were defended by Pan-Africanism and that were encompassed by the African Renaissance.

Flexibility and comprehensiveness end up demonstrating the cumulative character of the African Renaissance, as well as the possibility of expanding its means to achieve development and international insertion. Its cumulative character is evident in the fact that the creation of initiatives that reflect the existence of the African Renaissance in the current decade - such as the PIDA, AfCFTA and, in particular, Agenda 2063 - goes hand in hand with the maintenance of the NEPAD and the AU, both representing the materialisation of mutual responsibility and remaining, in the current period, increasingly relevant for the African continent. The possibility of expanding its means is verified since the distancing in relation to the notion of mutual responsibility has been followed by the adoption of what we call a hybrid strategy that is not a rejection (or complete abandonment) of the contestation and adaptation strategies, but, rather, is the re-structuring of a strategy based on the incorporation of elements found in both of them.

In addition to demonstrating the change in the African approach, hybridism represents the continent's ability to adjust to changes of power in international relations as a way of leveraging the search for the development of African countries, and of increasing the continent's autonomy. In other words, the implementation of the main initiative linked to such a strategy - in this case Agenda 2063 - will go hand in hand with the changes in the behaviour of the African continent, which may be aggressive, aggregative, or adaptive, depending on the international scenario. Therefore, changes that could possibly symbolise rupture or incoherence in the African way of acting, in fact, must be interpreted as a means of carrying this Renaissance further and, mainly, making the $21^{\text {st }}$ century the African century.

\section{Notes}

1 For more on the Casablanca and Monrovia groups, see Ki-Zerbo (1999) and Chanaiwa and Kodjo (2010).

2 South African President from 1999 to 2008.

3 By "silencing the guns" the AU means ending all wars, civil conflicts, gender-based violence, violent conflicts and preventing genocide in the continent.

4 The issue of financing is central not only to Agenda 2063 but also to the AU itself. Thus, in 2016 the Union initiated a process of institutional reform whose main objectives included making the AU financially more self-sufficient. The Kagame Reform, as it became known, however, has faced difficulties, and continues to be not fully implemented (Chekol 2020). 


\section{References}

Abdenur, A E. 2015. 'China in Africa, Viewed from Brazil.' The Journal of Asian Studies 74 (2): 257-267.

Abegunrin, O. 2009. Africa in Global Politics in the Twenty-First Century: A Pan African Perspective. New York: Palgrave Macmillan.

Abegunrin, O and C Manyeruke. 2020. China's Power in Africa: A New Global Order. Gewerbestrasse: Palgrave Macmillan.

Adebajo, A. 2013. The Curse of Berlin: Africa after the Cold War. Oxford: Oxford University.

Afreximbank. 2018. African Trade Report 2018 - Boosting Intra-African Trade: Implications of the African Continental Free Trade Area Agreement. [online]. At https://bityli.com/uG6Gq [Accessed on 5 September 2019].

African Union (AU). 2000. Constitutive Act of the African Union. African Union [online]. At https:// au.int/sites/default/files/pages/34873-file-constitutiveact_en.pdf [Accessed on 19 February 2021].

2015. Agenda 2063: The Africa We Want. African Union [online]. At https://au.int/ agenda2063/overview [Accessed on 5 September 2019].

African Union Commission (AUC). 2015. A Shared Strategic Framework for Inclusive Growth and Sustainable Development \& A Global Strategy to Optimize the Use of Africa's Resources for the Benefit of All Africans. Background Note. African Union. At https://au.int/sites/default/files/documents/33126-doc-01_background_note.pdf [Accessed on 5 September 2019]

Akinola, A and N Ndawonde. 2016. 'NEPAD: talking from the South, governing from the West.' International Journal of African Renaissance Studies 11 (2): 38-51.

Amorim, C. 2010. 'Brazilian foreign policy under President Lula (2003-2010): an overview.' Revista Brasileira de Política Internacional 53 (special issue): 214-240.

Badiru, I. 2016. 'NEPAD and Foreign Direct Investment in Africa.' Journal of Management and Social Sciences 5 (2): 15-31.

Barbosa, M. 2016. 'Pan-Africanismo e Relações Internacionais: Uma Herança (Quase) Esquecida.' Carta Internacional 11 (1): 144-162

Bujra, A. 2004. 'Pan-African Political and Economic Visions of Development From the OAU to the AU: From the Lagos Plan of Action (LPA) to the New Partnership for African Development (NEPAD).' DPMF 13: 1-32.

Burbach, D and C Fettweis. 2014. 'The Coming Stability? The Decline of Warfare in Africa and Implications for International Security.' Contemporary Security Policy 35 (3): 421-445.

Cardoso, N C F. 2019. Segurança Regional no Chifre da África (1974-2017): Conflitos, Atores, Agendas e Ameaças. PhD thesis, Universidade Federal do Rio Grande do Sul, Brazil.

Carmody, P. 2011. The New Scramble for Africa. Cambridge/Malden: Polity.

Cervenka, Z. 1977. The Unfinished Quest for Unity: Africa and the OAU. London: Julian Friedmann. Chabal, P. 2002. 'The Quest for Good Government and Development in Africa: Is NEPAD the Answer?' International Affairs 78 (3): 447-462.

Chanaiwa, D and E Kodjo. 2010. 'Pan-Africanismo e Libertação.' In A Mazrui and C Wondji (eds), História Geral da África - VIII: África desde 1935. Brasília: UNESCO, pp. 897-924. 
Chekol, Y G. 2020. 'African Union Institutional Reform: Rationales, Challenges and Prospects.' Insight on Africa 12 (1): 29-44.

Deghetto, K, J Gray and M Kiggundu. 2016. 'The African Union's Agenda 2063: Aspirations, Challenges, and Opportunities for Management Research.' Africa Journal of Management 2 (1): 93-116.

DeLancey, V. 2013. 'The Economies of Africa.' In A Gordon and D Gordon (eds), Understanding Contemporary Africa. Boulder/London: Lynne Rienner, pp.115-166.

De Waal, A. 2002. 'What's new in the 'New Partnership for Africa's Development'?' International Affairs 78 (3): 463-475.

Döpcke, W. 2002. 'Há Salvação para a África? Thabo Mbeki e Seu New Partnership for African Development.' Revista Brasileira de Política Internacional 45 (1): 146-155.

Fombad, C M. 2006. 'The African Union, Democracy and Good Governance.' In Henning Melber (ed), AU, NEPAD and the APRM Democratisation Efforts Explored. Uppsala: Nordiska Afrikainstitutet, pp. 9-39.

Frieden, F. 2008. Capitalismo Global. Rio de Janeiro: Zahar.

Haberson, J and D Rotchchild (eds). 2009. Africa in World Politics: Reforming Political Order. Boulder: Westview.

Hernandez, L M G L. 2008. A África na Sala de Aula: Visita à História Contemporânea. São Paulo: Selo Negro.

Hobsbawm, E. 1994. A Era dos Extremos (1914-1991): O Breve Século XX. São Paulo: Companhia das Letras.

International Trade Centre (ITC). 2018. Trade Map - International Trade Statistics. [online] At https://bityli.com/pDaKF [Accessed on 12 November 2018]

Ki-Zerbo, J. 1999. História da África Negra. Vol. 2. Mem Martins: Europa-America.

Kuwali, D. 2018. 'Squaring the Circle: The Role of the African Peace and Security Architecture.' In T Karbo and K Virk (eds), The Palgrave handbook of peacebuilding in Africa. Gewerbestrasse: Palgrave, pp. $45-63$.

Landsberg, C. 2012. 'Afro-Continentalism: Pan-Africanism in Post-Settlement South Africa's Foreign Policy'. Journal of African and Asian Studies 47(4): 436-448.

M’Bokolo, E. 2011. África Negra: História e Civilizações. Tomo II (Do Século XIX aos Nossos Dias). Salvador: EDUFBA.

Magee, J. 1971. 'What Role for E.C.A.?-Or Pan-Africanism Revisited.' The Journal of Modern African Studies 9 (1): 73-89

Mangala, J. 2010. 'Introduction: Africa and the New World Era: Context and Stakes.' In J Mangala (ed), Africa and the New World Era: From Humanitarianism to a Strategic View. New York: Palgrave Macmillan, pp. 1-20.

Manpilly, Z. 2014. 'India's sojourn to Africa.' In T Murithi (ed), Handbook of Africa's International Relations. London: Routledge, pp. 356-66.

Martin, G. 2002. Africa in World Politics: A Pan-African Perspective. Asmara: Africa World Press.

Mbeki, T. 1998. Speech by Deputy President Thabo Mbeki at the United Nations University the African Renaissance, South Africa and the World, United Nations University. [online]. At https://bityli.com/ K4Bmm [Accessed on 5 September 2013] 
Mendonça, M G. 2019. 'A Descolonização da África: Nacionalismo e Socialismo'. Sankofa 12 (22): 117-140. Milani, C. 2014. 'Brazil's South-South Co-Operation Strategies: From Foreign Policy to Public Policy.' Occasional paper n. 179. South African Institute for International Affairs, Johannesburg.

Murithi, T. 2009. 'Aid Colonisation and the Promise of African Continental Integration.' In H Abbas and Y Niyiragira (eds), Aid to Africa: Redeemer or Coloniser? Cape Town: Pambazuka, pp. 1-12.

Nagar, D and C Mutasa (eds). 2018. Africa and the World: Bilateral and Multilateral International Diplomacy. Gewerbestrasse: Palgrave Macmillan.

NEPAD Planning and Coordinating Agency (NEPAD Agency). 2011. NEPAD - A continental thrust: advancing Africa’s development. [online]. At https://bityli.com/xghwk [Accessed on 6 September 2019].

New Partnership for Africa's Development (NEPAD). 2001. The New Partnership for Africa's Development. [online]. At https://bityli.com/sPOIm [Accessed on 12 June 2018].

Oliveira, G Z, L Calvete and N Cardoso. 2015. 'Da Não Interferência da Organização da Unidade Africana à Não-Indiferença da União Africana: Percepções Africanas Sobre a Segurança do Continente.' SÉCULO XXI: Revista de Relações Internacionais - ESPM/Sul 5(1): 93-112.

Oliveira, G Z. 2015. 'A Intervenção Ocidental na Líbia: Interesses Ocidentais e o Papel da Liga Árabe.' Brazilian Journal of International Relations 4 (3): 670-93

Oliveira, G Z. 2018. 'A Nova Parceria para o Desenvolvimento Africano: uma análise dos impactos da NEPAD para o desenvolvimento da África no Século XXI.' Paper delivered at IV Seminário de Relações Internacionais da Associação Brasileira de Relações Internacionais. Foz do Iguaçu, Brasil, 27-28 September.

Otavio, A. 2017. 'Da Contestação à Responsabilidade Mútua: Uma Análise Entre o LPA e a NEPAD' Monções: Revista de Relações Internacionais da UFGD 6 (10): 196-218.

Ottosen, H. 2010. 'NEPAD's Contribution to Democracy and Good Governance in Africa.' International Institute for Democracy and Electoral Assistance. Stockholm: International IDEA.

Rodrigues, D and A C Caputo. 2014. O Projeto de Integração da África: Aspectos Físicos, Comerciais, Financeiros e de Investimento. Brasília: BNDES.

Schmidt, E. 2018. Foreign Intervention in Africa After the Cold War: Sovereignty, Responsibility and the War on Terror. Athens: Ohio University.

Taylor, I. 2005. NEPAD: Towards Africa's development or another false start? Boulder: Lynne Rienner. The Infrastructure Consortium for Africa (ICA). 2013. Infraestructure Financing Trends in Africa. [online]. At https://bit.ly/3gPD9Ty [Accessed on 10 July 2019].

. 2014. Infraestructure Financing Trends in Africa. [online]. At https://bit.ly/2W4eZNl [Accessed on 10 July 2019].

. 2018. Infraestructure Financing Trends in Africa. [online]. At https://bit.ly/2OckWTY [Accessed on 10 July 2019].

UNCTAD. 2011. Economic Development in Africa: Fostering Industrial Development in Africa in the New Global Environment. [online]. At https://bityli.com/TyH78 [Accessed on 10 September 2019]

.2018. Data Center. [online]. At https://bityli.com/865aS [Accessed on 15 November 2018]

Vigevani, T. 1994. Terceiro Mundo: Conceito e História. São Paulo: Editora Ática.

Wallerstein, I. 1967. Africa: The Politics of Unity. New York: Random House. 


\section{About the authors}

Guilherme Ziebell de Oliveira is Collaborating Professor of the Graduate Program in International Strategic Studies (PPGEEI) at the Federal University of Rio Grande do Sul (UFRGS) and Deputy Editor-in-Chief of the journal Conjuntura Austral: Journal of the Global South. He holds a PhD degree in Political Science from the Graduate Program in Political Science (PPGPol) at UFRGS and a Master's degree in International Strategic Studies from PPGEEI. He holds a double BA degree in International Relations and in Economics, both from UFRGS. His main research themes include issues related to the African continent and its countries, in the areas of International Political Economy, Security and Defense and International Politics.

Anselmo Otavio is Associate Professor of International Relations at the University of Vale do Rio dos Sinos (UNISINOS). He holds PhD and Master's degrees in International Strategic Studies from the Graduate Program in International Strategic Studies (PPGEEI) from the Federal University of Rio Grande do Sul (UFRGS), and a BA degree in International Relations from the Faculty of Philosophy and Sciences at the Universidade Estadual Paulista (FFC/UNESP). He is Associate researcher of the Brazilian Center for African Studies (CEBRAFRICA) and of the BRICS Study Center. His current research topics are African Renaissance, regional integration processes - notably initiatives aimed at economic integration - and South Africa's foreign policy. 


\section{As estratégias de desenvolvimento e inserção internacional da África: 0 Hibridismo da Agenda 2063}

Resumo: O presente trabalho discute a evolução das estratégias de desenvolvimento e inserção internacional adotadas pelo continente africano desde meados do século XX, quando suas nações passaram a alcançar a independência formal. Nesse contexto, e apoiado em revisão de literatura e de documentos oficiais de organizações do continente africano, busca-se compreender o significado e a importância da chamada Agenda 2063 para tal questão. A partir dessa análise, o artigo se propõe a demonstrar que tal agenda representa a inauguração de uma nova estratégia de desenvolvimento e inserção internacional do continente, denominada híbrida, uma vez que concilia elementos das duas abordagens adotadas anteriormente, as estratégias de contestação e de responsabilidade mútua e compartilhada.

Palavras-Chave: África; Pan-Africanismo; Renascimento Africano; desenvolvimento; estratégias; Agenda 2063.

Received on 10 July 2020, and approved for publication on 16 January 2021. 